\title{
CHARACTER EDUCATION IN THE LEARNING PROCESS FOR THE GENERATION OF THE NATION
}

\author{
Wiwik Widiyati, Dosen Fakultas Keguruan dan Ilmu Pendidikan, \\ Universitas Darussalam Ambon, \\ 081343218696 Wiwik_widiyati@yahoo.com
}

\begin{abstract}
Educational approaches that rely on physical and intellectual abilities alone will only give birth to children who are intellectually smart (logic, language, count), but weak in self-development skills and a positive attitude and understanding of the emotional values (teamwork, empathy, leadership, steadfast, patient, etc). While most people assume that the measure of success of one's children is the extent to which he is able to achieve high marks in the subjects taught, such as science, Mathematics, Foreign Language, and so on. In fact, this ability is only a small part of the key person's intelligence and success. Results of recent research shows that "kuntribusi" IQ (intellectual intelligence) at most about $20 \%$ of the success of the life course, so that the remaining $80 \%$ is determined by other factors, namely a set of factors called Emotional Intelligence (EQ) (Daniel Goleman in Emotional Intelligence).
\end{abstract}

\section{Keywords: Character, Education, Teaching}

Pendidikan adalah sebuah proses untuk mengubah jati diri seorang pserta didik untuk lebih maju. Menurut para ahli, ada beberapa pengertian yang mengupas tentang definisi dari pendidikan itu sendiri di antaranya menuru John Dewey, pendidikan adalah mwerupakan salah satu proses pembaharuan makna pengalaman. Sedangakan menurut H.Horne, pendidikan merupakan proses yang terjadi terus menerus (abadi) dari penyesuaian yang lebih tinggi bagi makhuk manusia yang telah berkembang secara fisik dan mental, yang bebas dan sadar kepada Tuhan, seperti termanifestasi dalam alam sekitar, intelektual, emosional, dan kemanusiaan dari manusia.

Selama ini para guru sudah mengajarkan pendidikan karakter namun kebanyakan masih seputar teori dan konsep, belum sampai ke ranah metodologi dan aplikasinya dalam kehidupan. Idelanya, dalam setiap proses pembelajaran mencakup aspek konsep (hakikat), teori (syariat), metode (tarikat), dan aplikasi (makrifat). Jika para guru sudah mengajarkan kurikulum secara komprehensif melalui konsep, teori, metodologi dan aplikasi setiap mata pelajaran di mana pendidikan karakter sudah terimplementasi di dalamnya, maka kebermaknaan yang diajarkannya akan lebih efektif dalam emnunjang 
pendidikan karakter. Tanpa pijakan dan pemahaman tebtang konsep, teori serta metode yang jelas dan komprehensif tentang pendidikan karakter, maka misi pendidikan karakter pada sekolah-sekolah akan menjadi sia-sia.

Dalam implementasinya, pendidikan akhlak masih sama halnya dengan pendidikan moral. Walaupun beberapa lembaga pendidikan sudah menyatakan berbasis moral dan akhlak, tetapi masih berbanding lurus dengan naiknay angka kriminalitas dan dekadensi moral di kalangan anak sekolah. Sedangkan pendiidkan karakter merupakan uapaya pembimbingan perilaku siswa agar mengetahui, mencintai, dan melakukan kebaikan. Fokusnya pada tujuan-tujuan etika melalui proses pendalaman apresiasi dan pembiasaan.

\section{METODE PENELITIAN}

Penelitian ini menggunakan pendekatan library research dengan mengumpulkan data dari berbagai sumber literatur yang diperoleh pada perpustakaan

\section{HASIL DAN PEMBAHASAN}

\section{PENTINGNYA MEMBANGUN KARAKTER}

Karakter memberikan gambaran tentang suatu bangsa, sebagai penanda, penciri sekaligus pembeda suatu bangsa dengan bangsa lainnya. Karakter memberikan arahan tentang bagaimana bangsa itu menapaki dan melewati suatu jaman dan mengantarkannya pada suatu derajat tertentu. Bangsa yang besar adalah bangsa yang memiliki karakter yang mampu membangun sebuah peradaban besar yang kemudian mempengaruhi perkembangan dunia.

Langkah-langkah penerapan pendidikan karakter untuk menjadi budaya sekolah:

a. Kesepakatan mengenai karakter yang hendak dicapai dan ditargetkan sekolah. Karena tidak mungkin satu sekolah dapat menetapkan ke-18 karakter yang ditetapkan oleh Kemendikbud.

b. Membangun pemahaman bahwa sekolah ingin membudayakan karakter positif untuk seluruh warga sekolah dan ini membutuhkan sebuah proses.

c. Menyusun rencana menyeluruh untuk mengintensifkan pengembangan dan pembelajaran mengenai karakter yang hendak dicapai atau ditargetkan sekolah.

d. Mengintegrasikan karakter yang sudah dipilih ke dalam pembelajaran di seluruh kurikulum secara terus-menerus.

e. Melalui suatu workshop, para guru harus menentukan pendekatan/metode yang jelas terhadap mata pelajaran yang dapat digunakan untuk menanamkan karakter yang sudah disepakati sekolah. Contoh: pendidikan anti korupsi.

f. Sosialisasikan karakter yang sudah disepakati kepada seluruh warga sekolah. 
g. Mengmbangkan moto (semboyan) sekolah, yang bertumpu pada karakter yang disepakati.

h. Menentukan indikator (petunjuk) terhadap keberhasilan program ini.

i. Melakukan evaluasiterhadap program karakter

j. Memberikan apresiasi bagi warga sekolah yang menunjukkan perubahan ke arah karakter yang dibudayakan.

Selama ini, pendidikan karakter di sekolah dibebankan dan disandarkan pada bidang studi pendidikan pancasila dan Kewarganegaraan (PPKn), kemudian berganti nama menjadi menjadi Pendidikan Pancasila dan Kewarganegaraan (PKn).

Membangun karakter bangsa menjadi tanggung jawab bersama semua pihak dan komponen dari bangsa ini untuk terlibat menyingsingkankan lengan baju membangun karakter yang kuat dan khas. Semua potensi bangsa haruslah bangkit dan bersatu padu untuk melakukan sebuah gerakan dan tindakan dalam membangun karakter bangsa agar negeri ini bangkit dan meraih cita-cita besarnya sehingga mampu sejajar dengan bangsabangsa besar lain di dunia dan mampu memberikan kontribusi bahkan menjadi pusat peradaban. Semua itu tentu haruslah bermula dari semangat, visi, dan keteladanan yang dimunculkan dalam diri para pemimpinnya, demikianlah yang pernah dialami oleh negara-negara besar lainnya. Sehingga semua lini kehidupan harus bergerak secara terpadu melakukan sebuah revolusi mental dalam membangun karakter bangsa mulai dari unsur paling terkecil dalam struktur masyarakat, yaitu keluarga, kemudian lembaga pendidikan, lingkungan sosial masyarakat melalui pemimpin-pemimpin sosial seperti tokoh masyarakat, pemimpin RT/RW, pemimpin daerah (kelurahan/desa, kecamatan, kota, kabupaten), pemimpin tingkat regional, gubernur hingga pemimpin tingkat nasional, anggota legislatif, menteri, presiden. Semua harus bergerak bersama, bersatu padu dalam sebuah irama yang sama utnuk membangun karakter bangsa dengan nilainilai luhur yang dipahami bersama.

Dari sinilah kemudian semua unsur masyarakat harus terlibat membangun karakter generasi, antara lain:

a. Keluarga harus ikut terlibat membangun karakter generasinya melalui kepedulian dan keteladanan orang tua dengan cara memperkenalkannya sejak dini dan mendampingi generasi. Struktur terkecil masyarakat ini menjadi kunci awal dalam pembentukan nilai karakter bangsa. Keluarga adalah pembentuk paling signifikan dalam diri seseorang. Kita mengenal arti baik dan buruk dari keluarga melalui apa yang sering dilihat, didengar dalam keluarga, ucapan, tindakan yang ditampilkan khususnya oleh orang tua. Sehingga kita mengenal sebuah ungkapan bahasa arab "al ummu madrasatul "ula" ibu adalah tempat pendidikan pertama dalam kehidupan seorang manusia. 
b. Kalangan pelaku lembaga pendidikan di mana pun tingkat dan stafnya khususnya sejak pendidikan dasar, yaitu PAUD, TK, SD, kemudian tingkat yang lebih tasnya SMP, SMP hingga perguruan Tinggi oleh para pendidik (guru, dosen dsb) juga harus terlibat membangun karakter melalui penanaman nilai dan penguatan nilai-nilai karakter itu dengan cara mengajarkannya dan mendidiknya.

c. Organisatoris (termasuk dalam organisatoris adalah para pekerja, karyawan, aktivitas organisasinya, organisasi profesional, pemerintahan ataupun lembaga dan institusi lainnya): mempraktikkannya dan memberikan contoh teladan terbaik. Belajar dari model masyarakat kita yang patron klien yaitu masyarakat yang sangat tergantung pada patron yang ada di atasnya, mereka hanya akan bersedia berubah dengan meniru setiap perilaku yang ditampilkan oleh mereka yang menjadi patronnya, yaitu mereka yang dianggap sebagai pimpinanannya, mereka yang di-tuakan, yang secara sosial dan psikologis dianggap berada di "atasnya".

\section{MEMBANGUN KARAKTER}

a. Melalui keteladanan

Darisekian banyak metode membangun dan menanamkan karakter, metode inilah yang paling kuat. Karena keteladanan memberikan gambaran secara nyata bagaimana seseorang harus bertindak. Keteladanan berarti kesediaan setiap orang untuk menjadi contoh dan miniatur yang sesunagguhnya dari sebuah perilaku. Keteladan harus bermula dari diri sendiri. Di dalam Islam, keteladanan bukanlah hanya semata persoalan mempengaruhi orang lain dengan tindakan, melainkan sebuah keharusan untuk melakukan tindakan itu yang berhubungan langsung secara spiritual dengan Allah SWT. Karenanya, tidak adanay contoh keteladanan akan mengakibatkan kemurkaan dari Allah SWT sebagimana FirmanNya: "Wahai oprang-orang yang beriman, kenapakah kamu mengatakan sesuatu yang tidak kamu kerjakan? Amat besar kebencian di sisi Allah bahwa kamu mengatakan apa-apa yang tidak kamu kerjakan” (QS. Ash-Shaff, 61:2-3).

Jika anda adalah orang tua, maka berikan contoh kepada anak-anak bagaimana bersikap yang terbaik itu, begitu jug jika seorang guru, pimpinan orgnisasi, institusi, atau perusahaan, maka tampakkan kebaikan sikap itu kepada anak-anak, bukan dengan katakata. Mulailah tindakan-tindakan keteladanan itu dari hal-hal yang mungkin terkesan sepele, remeh, dan kecil. Karena tindakan-tindakan kecil akan membentuk sebuahn puzzle tindakan yang tersusun dengan rapi dalam memori bawah sadar anda dan anak, murid ataupun karyawan sehingga menjadi sebuah dasar bagi tindakan yang lebih besar lagi. Misalnya, ambilkan air minum untuk rekan anda saat makan bersama sebagai tanda kepedulian, rapikan sandal di rumah dengan posisi menghadap keluar untuk mengajarkan pada anak tentang kesiapan, kerapian, kedisiplinan dan sebaginya. 
b. Melalui simulasi praktek (experiential learning)

Dalam proses belajar, setiap informasi akan diterima dan diproses melalui beberapa jalur dalam otak dengan tingkat penerimaan yang beragam. Terdapat enam jalur menuju otak, antara lain melalui apa yang dilihat, didengar, dikecap, disentuh, dicium, dan dilakukan. Bahkan Confucius, 2400 tahun lalu mengatakan:

What I Hear, I Forget. What I See, I Remember. What I Do, I Understand.

Apa yang saya dengar, saya lupa. Apa yng saya lihat saya ingat. Apa yang saya lakukan saya paham.

Sehingga Mel Siberman, mengatakan bahwa apa yang saya dengar, saya lupa. Apa yang saya dengar dan saya lihat, saya ingat sedikit, apa yang saya dengar lihat dan tanyakan atau diskusikan dengan beberap teman lain, saya mulai faham. Apa yang saya dengar, lihat, diskusikan dan lakukan, saya memperoleh pengetahuan dan ketrampilan. Apa yang saya ajarkan pada orang lain, saya kuasai. Pada masing-masing jalur dtersebut memiliki tingkat persentase afektifitas yang berbeda-beda. Dari sekian jalur yang ada tersebut, tindakan atau aksi jauh lebih kuat dalam membangun informasi di otak manusia dari apa yang dilihat, didengar, dan sebagainya. Oleh karena itu, membangun karakter dapat dilakukan dengan menggunakan simulasi praktik, melalui bermain peran (role play), demonstrasi sikap yaitu mengajak anak untuk memainkan peran sebuah sikap dan karakter positif tertentu, apakah dalam bentuk drama ataupun tindakan nyata dengan berinteraksi pada sebuah sikap tertentu secara langsung.

c. Menggunakan metode ikon dan afirmasi (menempel dan menggantung).

Memperkenalkan sebuah sikap positif dapat pula dilakukan dengan memprovokasi semua jalur menuju otak kita khususnya dari apa yang kita lihat melalui tulisan atau gambar yang menjelaskan tentang sebuah sikap positif tertentu. Misalkan dengan tulisan afirmasi dan ikon-ikon positif yang ditempelkan atau digantungkan di tempat yang mudah untuk kita lihat. Sehingga diri kita akan sering melihatnya yang kemudian akan memprovokasi pikiran dan tindakan untuk mewujudkannya dalam realitas. Tulisan afirmasi ataupun ikon ini dapat dibuat berganti-ganti dalam skala waktu tertentu. Hal ini disesuaikan dengan nilai-nilai apa saja yang ingin kita bangun pada anak, murid, ataupun karyawan kita. Tulisan afirmasi itu bisa berupa kalimat positif yang bersifat motivatif.

d. Menggunakan Metode Repeat Power

Yaitu dengan mengucapkan secara berulang-ulang sifat atau nilai positif yang ingin dibangun. Metode ini dapat pula disebut dengan metode Dzikir Karakter. Di Jepang, metode ini dipergunakan untuk mempersiapkan para pemimpin muda perusahaan untuk memformulasikan pikirannya agar mampu mewujudkan segala apa yang dicita-citakan. Mereka kemudian dimasukkan dalam sebuah training center di kuil-kuil Shinto, 
kemudian para instruktur mewajibkan para peserta yaitu para calon eksekutif muda tersebut untuk mengucapkan kalimat "Saya Juara!" seratus kali dalam sehari selama masa latihan. Hasilnya ternyata luar biasa! Sekarang kita bisa melihat bagaimana perusahaanperusahaan Jepang mampu menjadi perusahaan yang hebat dan terbesar serta juara di tingkat dunia.

Metode Repeat Power adalah salah satu cara untuk mencapai sukses dengan menanamkan sebuah pesan positif pada diri kita secara terus menerus tentang apa yang ingin kita raih. Otak kita membutuhkan suatu provokasi yang dapat mendorongnya memberikan suatu instruksi positif pada diri kit untuk melakukan tindakaqn-tindakan positif yang dapat mengantarkan pada realitas sukses yang diharapkan. Ibarat air walaupun dia halus dan lembut, namun apabila dijatuhkan secara terus menerus pada satu titik di suatu batu yang keras sekalipun maka pastilah batu tersebut akan hancur atau setidaknya berlobang. Demikian pula pesan yang begitu halus apabila diucapkan secara terus-menerus pada pikiran kita akan menghasilokan sebuah energi besar yang akan mendorong pada terwujudnya sesuatu sebagaimana yang dimaksudkan dalam pesan tersebut. Metode ini bisa dilakukan dengan cara mengulang-ulang nilai sikap positif dalam sebuah yel-yel lembaga setiap atau sebelum memulai aktifitas (proses belajar mengajar atau sebelum memulai pekerjaan).

\section{e. Metode 99 Sifat Utama}

Metode ini adalah melakukan penguatan komitmen nilai-nilai dan sikap positif dengan mendasarkan pada 99 Sifat Utama (Asma'ul Husna) yaitu pada setiap harinya orang memilih salah satu sifat Allah (Asmaul Husna) secara bergantian kemudian menuliskan komitmen perilaku aplikatif yang sesuai dengan sifat tersebut yang akan dipraktikkan paqda hari itu. Tulisan tersebut diletakkan di meja atau d tempat yang mudah dilihat. Misal: Ar Rahman (Maha Pengasih), komitmen sikap aplikatifnya adalah: Hari ini, saya akan menunjukkan kasih sayang kepada siapapun. Pada hari itu anda kuatkan komitmen untuk mengaplikasikan dan menunjukkan sikap tersebut melalui tindakan-tindakan nyata sekecil dan sesepele apa pun.

f. Membangun kesepakatan nilai keunggulan

Baik secara pribadi atau kelembagaan menetapkan sebuah komitmen bersama untuk membangun nilai-nilai positif yang akan menajadi budaya sikap atau budaya kerja yang akan ditampilkan dan menjadi karakteer bersama. Nilai sikap yang dipilih dapat dijadikan yel-yel ataupun lagu yang wajib dilantunkan kapan pun saja, saat akan memulai pekerjaan atau menutup pekerjaan.

g. Melalui Penggunaan Metafora

Yaitu dengan menggunakan metode pengungkapan cerita yang diambil dari kisahkisah nyata ataupun kisah inspiratif lainnnya yang disampaikan secara rutin kepada setiap 
orang dalam institusi tersebut (siswa, guru, karyawan dll) dan penyampaian kisah motivasi inspiratif tersebut dapat pula selalu diikutsertakan pada setiap proses pembelajaran atau sesi penyampaian motivasi pagi sebelum memulai pelajaran.

\section{KONSEP DASAR MEMBANGUN KARAKTER DENGAN HATI NURANI}

Suatu ketika pada awal penciptaan manusia terdapat percakapan yang sangat menarik antara malaikat dengan Allah Sang Pencipta di saat Allah Sang Pencipta mengutarakan kehendak Nya untuk menciptakan manusia sebagai pengelola dan pemimpin (khalifah) kehidupan di bumi. Maka mendengar hal itu para malaikat berkata: "Mengapa Engkau hendak menjadikan di bumi itu orang yang akan membuat kerusakan din sana dan menumpahkan darah, padahal kami senantiasa bertasbih dengan memuji Engkau dan mensucikan Engkau?", namun apa yang dikatakan Allah sang Pencipta selanjutnya. "Sesungguhnya Aku mengetahui apa yang tidak kamu ketahui". Ternyata benar para malaikat tidak mengetahui skenario Allah SWT yenyang penciptaan manusia ini dan segala rahasia yang ada di balikipenciptaan tersebut.

Allah telah menjadikan manusia dengan segala keajaiban penciptaan dan kemampuan yang sangat luar biasa sebagi modal dasar bagi mereka untuk mengelola kehidupan. Semenjak awal penciptaan manusia, mereka telah diberi kemampuan sebagai pemenang sejati dan bahkan status menjadi pemenang telah dilekatkan pada diri manusia sebagai watak dasarnya. Sejarah kemenangan telah dimulai semenjak manusia masih berupa sel sperma sebagai bahan baku penciptaannya. Sebagaimana Firman-Nya: Dan Dia yang menciptakan manusia daria air mani lalu dia jadikan manusia itu keturunan dan mushaharah dan adalah Tuhanmu Maha Kuasa (QS. Al-Furqaan, 25:54).

Demikian pula dalam Firman-Nya: "Maka hendaklah manusia memperhatikan dari apakah dia diciptakan? Dia diciptakan dari air yang dipancaqrkan" (QS.Ath-Thaariq, 82: 5-6). Pada waktu itu sekitar 250 juta sel sperma bersamaan dikirim ke rahim sang ibu, mereka semua berkompetisi untuk menunjukkan siapa diantara mereka yang terbaik dan mampu menjadi pemenang (the winner) dalam perlombaan untuk menjadi manusia. Segera setelah sperma-sperma ini memasuki tubuh sang ibu mereka berhadapan dengan bahaya yang mematikan karena di dalam organ reproduksi sang ibu terdapat campuran asam pekat yang menghalangi pertumbuhan bakteri begitu pula terhadap sperma. Sehingga dapatlah dipastikan hanya dalam beberapa menit atau jam kemudian sebagian besar kompetitor yang berjumlah jutaan itu gugur, dan hanya ada satu yang diperkenankan untuk terus mampu bertahan guna melanjutkan perjalanan panjangnya untuk mewujudkan dirinya sebagai pemenang sejati, siapakah dia? Jawabnya, ANDA!!!, Andalah sang pemenang dan pemimpin sejati. Inilah fitrah kepemimpinan yang ada dalam diri setiap manusia sejak awal penciptaannya. 
Ketika anda menginginkan sebuah puncak kesuksesan sebagai pemenang sejati dalam hidup ini, maka landasan utama sebagai modal dasar kemenangan itu haruslah anda miliki (Basic Winning), yaitu ketajaman dalam membangun visi ke depan tentang apa yang akan dicapai. Di saat menginginkan masa depan yang dicita-citakan itu, karena semuanya berawal di dalam pikiran anda. Di saast anda berpikir menang maka anda menang, begitu sebaliknya. Kunci kemenangan kedua adalah kemenangan indivual Anda (Personal Winning), sebuah kemenangan awal sebelum Anda memenangkan kompetensi dengan pihak luar. Keberhasilan Anda mengenal dan mengelola diri Anda sendiri mengantarkan Anda pada kemenangan dihadapan publik. Pengenalan diri dan pembangunan kompetensi diri yang akhirnya mengantarkan Anda dalam penciptaan hidup yang efektif merupakan modal dasar dalam melakukan interaksi dengan kehidupan. Janganlah Anda berharap akan mampu mengelola dan menjadi pemimpin masa depan jika Anda tidak mampu mengelola dan memimpin diri Anda sendiri.

Kemenangan sosial akan Anda raih manakalah Anda mampu bersikap peka, selanjutnya mampu melakukan perubahan sosial dan menjadi yang terdepan dalam perubahan sosial tersebut. Eksistensi anda dalam kehidupan sebenarnya dapat dilihat pada sejauh mana peran yang anda mainkan di tengah-tengah kehidupan itu sendiri. Anda baru akan diakui dalam kehidupan di saat Anda mampu turut serta membangun sejarah perdaban masa depan terbaik.

Puncak kemenangan Anda di saat Anda mampu bersikap istiqomah, ajeg dalam menampilkan sikap-sikap dan kebiasaan terbaik yang mampu mengantarkan Anda sebagai pemimpin kehidupan. Istiqomah adalah sebuah proses perjalanan panjang menampilkan sikap terbaik yang akhirnya menjadi sebuah kebiasaan dan karakter dalam kehidupan menuju pribadi yang anggun sebagai pemenang yang sejati.

\section{PENDIDIKAN KARAKTER DALAM PRAKTIK KELAS YANG AKTIF, KREATIF, KRITIS, DAN BERKARAKTER}

Ada sejumlah idealisme dan pandangan yang melandasi gerak langkah dan pemikiran saya dalam mewujudkan proses pembelajaran yang menyenangkan dan membebaskan. Berbagai pandangan dan idealisme tersebut memang bersifat universal dan diyakini sebagai paradigma pendidikan progresif. Berikut ini saya uraikan cara pandang yang saya maksud tersebut sebagai berikut:

Pertama, pandangan terhadap pendidikan. Pendidikan adalah sebuah proses sadar dan terencana untuk terus mendorong perubahan serta pembaharuan individu dan sosial untuk mencapai mutu kehidupan yang lebih baik, dengan cara memaksimalkan kemerdekaan pribadi peserta didik, serta membela kondisi kemanusiaan dalam lingkungan sosialnya. Faktor mendasar dalam pendidikan adalah proses "mengada" (being) si anak. Faktor lain di luar diri anak adalah sasaran-sasaran sosial, makna-makna, 
dan nilai-nilai yang terwujud dalam pengalaman sejarah orang dewasa. Faktor lain adalah media yang memungkin interaksi antara faktor anak dan faktor orang dewasa, itulah intisari teori pendidikan. Nada dasarnya adalah kasih sayang dan simpati.

Kedua, pandangan terhadap anak sebagai warga belajar. Setiap manusia lahir sebagai pribadi yang unik. Perbedaan-perbedaan pribadi anak lebih penting daripada kesamaannya. Potensi perbedaannya yang menentukan proses pembelajaran dan posisi masa depannya. Seorang anak hidup dalam dunia dengan kontak-kontak personal sempit yang membentuk teman-teman dalam suatu totalitas kehidupannya. Anak-anak dipandang setara secara moral, mendapat kesempatan setara dalam berjuang demi ganjaran sosial dan intelektual, serta memperoleh kesempatan secara luas dan mudah diakses yang dibagikan secara adil. Tetapi kompetensi pribadi tumbuh melalui belajar dari pengalaman, lalu berkembang membentuk diri sebagai pribadi yang unik dalam proses yang berkelanjutan sepanjang hayat.

Ketiga, pandangan terhadap materi kurikulum. Kehidupan anak merupakan totalitas walau dalam dunia anak yang sempit. Hal yang menyibukkan benaknya diikat oleh fisik dan kepentingannya. Yang paling menguasai pikirannya adalah segalanya pada saat itu. Kemudian ia pergi ke sekolah, menemukan bidang-bidang studi, yang membagibagi dan memecah belah dunia. Ada sejumlah mata pelajaran sebagai penggolonggolongan subyek. Fakta dirobek dari tempat aslinya lalu ditata kembali dalam prinsip umum ilmu pengetahuan. Penggolongan bukan bagian dari pengalaman dunia anak. Bidang studi yang dibagi dalam bab-bab atau bagian-bagian adalah produk ilmu pengetahuan sepanjang sejarah peradaban manusia berabad-abad, bukan produk dan pengalaman anak yang terbatas. Anak tangkas dan cepat bisa berpindah dari satu tema ke tema lain bahkan tanpa menyadari transisi. Itulah suasana belajar dan proses pembelajaran yang integral, tematik, dan sesuai dengan kemampuan perkembangan psikologi anak.

Keempat, pandangan terhadap proses belajar. Keberhasilan suatu proses pembelajaran lebih terkait langsung dengan siswa sebagai subjek dan warga belajar. Oleh karenanya perlu pengutamaan partisipasi siswa dalam menentukan model dan proses belajar. Melibatkan peserta didik ke dalam proses pembelajaran agar mereka aktif mengembangkan potensi dirinya. Mereka belajar dari apa yang dikerjakannya dalam medium yang terkandung pesan. Keberhasilan pendidikan ditentukan oleh media pembelajaran (65\%), guru, alat tulis dan meja kursi dalam kelas, buku pelajaran, fasilitas dan lingkungan, serta faktor lain (35\%).

Ki Hajar Dewantara, pendidik, pemikir, dan pejuang Indonesia yang hidup di masa kolonial Belanda dan masa revolusi kemerdekaan, memiliki perspektif pendidikan yang kritis bahkan kemudian berhadapan langsung dengan kolonialisme hingga berisiko 
diasingkan dari negeri tercinta ini. Pemikiran kritis Ki Hajar bisa ditelusuri ketika tokoh pendidikan ini memahami manusia. Menurut Ki Hajar, manusia memiliki daya jiwa yaitu cipta, karsa, dan karya. Dari perspektif ini Ki Hajar amat kritis terhadap realitas dunia pendidikan. Beliau mengatakan bahwa pendidikan yang menekankan pada aspek intelektual belaka akan menjauhkan peserta didik dari masyarakatnya. Realitas masyarakat seolah jauh dari dunia pendidikan. Realitas ini sesungguhnya menggambarkan juga bahwa pendidikan justru melakukan dehumanisasi karena olah rasa dan olah karsa tidak dijadikan agenda pendidikan. Jika aspek intelektual saja yang terus mendominasi proses pembelajaran maka akan berakibat pada tidak hanya pada munculnya dehumanisasi tetapi juga kehilangan akar kebudayaannya. Padahal kebudayaan adalah faktor penting yang turut menjadikan manusia lebih humanis.

Selain Ki Hajar, dalam literasi kritis pendidikan Indonesia kita pun mengenal Tan Malaka. Pandangan Tan Malaka atas pendidikan sangat luar biasa. Baginya, pendidikan bertujuan untuk mempertajam pikiran dan menghaluskan perasaan. Dalam sebuah diskusi tentang metode literasi kritis dalam pendidkan pancasila, Ubedillah (dosen dan aktivis pendidikan) menguraikan pandangan Tan Malaka atas pendidikan sebagai berikut: "menurut Tan Malaka, pendidikan harus dimaknai sebagai proses untuk mewujudkan peserta didik menjadi orang yang baik dan bajik. Pendidikan yang menciptakan manusia yang baik dan bijak akan memberi kekuatan kepada peserta didik. Karena itulah, menurut Tan Malaka, pendidikan akhlak harus menjadi tujuan utama (Poeze, 200:121)".

Tan Malaka juga sangat menekankan bahwa pendidikan anak-anak tidak hanya sebatas kognitif, seperti mempelajari Sejarah, Ilmu Bumi, dan Ilmu Hitung seperti yang sangat ditekankan di banyak sekolah-sekolah Eropa pada masa itu. Tan Malaka memandang bahwa pendidikan berkewajiban untuk menanamkan etos kerja dan keterampilan-keterampilan praktis yang akan memunculkan kepada pribadi untuk mencintai kerja, dan seharusnya pendidikan pun memberikan nilai tambah. Tan Malaka juga memberikan perhatian khusus untuk anak-anak para kuli/buru. Pendidikan untuk anak-anak para kuli dan buruh ditunjukkan agar otak mereka lebih tajam dan berkemauan lebih kuat, disamping menghaluskan perasaan-perasaan mereka, seperti apa yang menjadi cita-cita pendidikan setiap bangsa atau golongan di negeri manapun. Disamping memajukan otak, daya kemampuan, dan perasaan, maka perlu dikembangkan pula kehendak dan kebiasaan anak-anak untuk melakukan pekerjaan tangan serta perasaan bahwa pekerjaan itu penting artinya, setara dengan pekerjaan otak (Poize, 2000:121). 


\section{DAFTAR PUSTAKA}

Arikunto Suharsimi. 2002. Dasar-dasar Evaluasi Pendidikan Cet.III. PT. Bumi Aksara. Jakarta.

Departemen Pendidikan dan Kebudayaan RI. 1993. Kamus Besar Bahasa Indonesia, edisi ke 2. Balai Pustaka. Jakarta.

Miarso Yusufhadi. 2005. Menyemai Benih Teknologi Pendidikan. Kencana. Jakarta

N.Y. Rustaman, dkk. 2003. Strategi Belajar Mengajar Biologi. JICA-UPI. Bandung: Poedjiadi Anna. 2005. Sains Teknologi Masyarakat. PT.Remaja Rosdakarya. Bandung

Purwanto M. Ngalim. 1998. Prinsip-Prinsip dan Teknik Evalusi Pengajaran. PT.Rosdakarya. Jakarta.

Sabri Alisuf. 1996. Psikologi Pendidikan Cet.II. Pedoman Ilmu Jaya. Jakarta.

Sanjaya Wina. 2007. Strategi Pembelajaran Berorentasi Standar Proses Pendidikan. Kencana Prenada Media Group. Jakarta.

Slameto. 2003. Belajar dan Foktor-Faktor Yang Mempengaruhinya. Rineka Cipta. Jakarta:

Sudiono Anas. 1999. Pengantar Statistik Pendidikan. Raja Grafindo Persada. Jakarta:

Suparno. P. 1997. Filsafat Konsrtuktivisme Dalam Pendidikan. Kanisius. Yogyakarta.

Syah Muhibbin. 2004. Psikologi Pendidikan Dengan Pendekatan Baru Cet. IX. PT.Remaja Rosda karya Offset. Bandung. 